\title{
25 Ma Explosive volcanism produced by magma immiscibility in the Rukwa Rift, western branch of the East African Rift System
}

LEIGH LAWRENCE * ,CARL SPANDLER', ERIC ROBERTS

HANNAH HILBERT-WOLF'

James Cook University, Townsville, Australia.

*leigh.lawrence@my.jcu.edu.au

The earliest stages of continental rifting produce some of the most distinctive alkaline magmas on Earth. However, rare exposure, poor chemical preservation and the dynamic setting in which they occur sees these early volcanic rocks under-represented in the geologic record. The Nsungwe Formation airfall tuffs of the Rukwa Rift Basin (southwestern Tanzania) are the eruptive products of the earliest known episode of volcanism associated with the $\sim 25$ Ma initiation of the western branch of the East African Rift System. Today these volcanic deposits are extensively altered clay-dominated horizons rich in the resistant minerals apatite, andradite, phlogopite, sanidine, pyrochlore, calcite and titanite.

This study focuses on titanite and their pristine silicate glass inclusions. Using a variety of in-situ microanalytical techniques (i.e. EMPA, LA-ICPMS, LA-MC-ICPMS), we gathered major element, trace element and $\mathrm{Sm}-\mathrm{Nd}$ isotope concentrations for a suite of large (30-100 $\mu \mathrm{m})$ melt inclusions and their titanite hosts. With these data, we trace the evolution of this previously undescribed volcanic system from peralkaline phonolite towards peraluminous dacitic compositions; a magma evolution that is incompatible with pure crystal fractionation or crustal contamination. Instead, we model this magma evolution using a combination of carbonatite liquid immiscibility and multi-stage crystal fractionation processes and in doing so, present a new model for generating volatile-rich silicic magma of explosive constitution.

Titanite is shown to be a powerful petrological tool capable of reliably recording and preserving the evolution of alkaline magmatic systems. The novelty of our approach and distinctive nature of volcanism in the early Rukwa Rift highlights the research potential of this common, yet underutilised accessory mineral phase. The resulting magma evolution and explosive volcanic character presented here may have important controls on the behaviour and evolution of intraplate volcanism globally, and throughout the geologic record. 